\title{
KONFERENCJA NAUKOWA: „BOGURODZICA NA LUDZKICH DROGACH ŻYCIA”. SOKOŁÓW MAŁOPOLSKI, 20 MAJA 2010 R.
}

\author{
Witaj, Maryjo, chwałą ozdobiona, \\ Tu w Sokołowie, łaskami wsławiona, \\ Matko Chrystusa i Niepokalana, \\ A nasza Matko droga, ukochana. (...) \\ Maryjo, Ciebie błagamy ze łzami: \\ Miej nas w opiece i króluj nad nami. \\ (z pieśni XIX-wiecznej)
}

Społeczność parafii w Sokołowie Małopolskim od dawna już przygotowuje się na doniosłą uroczystość koronacji łaskami słynącego wizerunku Pani Sokołowskiej - Opiekunki Ludzkich Dróg. Wśród widocznych znaków tych przygotowań należy wymienić podejmowane przez proboszcza ks. Jana Prucnala prace renowacyjne przy sokołowskiej farze - sanktuarium Królowej Świata. Ukazały się także publikacje poświęcone obrazowi: Łaskami stynący obraz NMP Królowej Świata - Opiekunki Ludzkich Dróg w Sokołowie Małopolskim (Lublin-Rzeszów 2008) i Pod płaszczem Maryi (Sokołów Małopolski 2009). Wydano też album prezentujący kościół pw. św. Jana Chrzciciela w Sokołowie, miejsce w którym cześć odbiera Maryja w cudownym wizerunku. Sokołowska Biblioteka Publiczna przy współpracy z miejscową parafią zorganizowała dwie wystawy połączone z sympozjami naukowymi: Domus Dei (poświęconą kościołowi farnemu) i Pod ptaszczem Maryi (dotyczącą wizerunku Matki Bożej Sokołowskiej).

W ramy przygotowań do koronacji dobrze wpisała się także Ogólnopolska Konferencja Naukowa „Bogurodzica na ludzkich drogach życia”, która miała miejsce w dniu 20 maja 2010 r. Zorganizowały ją: Instytut Badań nad Polonią i Duszpasterstwem Polonijnym Katolickiego Uniwersytetu Lubelskiego Jana Pawła II, Parafia Rzymskokatolicka pw. św. Jana Chrzciciela w Sokołowie Małopolskim oraz Miejska i Gminna Biblioteka Publiczna w Sokołowie Małopolskim. Wśród celów, które przyświecały organizatorom, wymienić należy: propagowanie kultu i oddanie czci Matce Bożej, czczonej w łaskami słynącym wizerunku, 
przygotowania do koronacji obrazu, a także chęć refleksji nad tematyką emigracyjną i duszpasterstwem polonijnym w kontekście tytułu Matki Bożej Królowej Świata - Opiekunki Ludzkich Dróg. Patronat nad wydarzeniem przyjęli: ordynariusz rzeszowski bp Kazimierz Górny, delegat Konferencji Episkopatu Polski ds. duszpasterstwa emigracji polskiej bp Wojciech Polak oraz dyrektor Instytutu Duszpasterstwa Emigracyjnego w Poznaniu ks. dr Wiesław Wójcik TChr.

Konferencja rozpoczęła się Mszą św. sprawowaną w kościele pw. Ducha Świętego. To miejsce celebry wybrano nie tylko ze względu na bliskość sali obrad. Pierwotnie było ono silnie związane z cudownym wizerunkiem, gdyż tam właśnie odbierał on część. Wspomina o tym m.in. ks. Sadok Barącz w opracowaniu Cudowne Obrazy Matki Najświętszej w Polsce: „Podczas morowego powietrza, gdy mnóstwo ludzi chowano za okopem, pewnego dnia mglistego ukazała się osoba biała w powietrzu, które to zjawisko dało pochop do wybudowania kościołka Świętego Ducha i umieszczenia w nim obrazu Matki Najświętszej wśród aniołów do nieba wziętej"1.

Liturgii przewodniczył delegat biskupa ordynariusza - ks. infuł. dr Wiesław Szurek, wikariusz biskupi ds. formacji stałej kapłanów diecezji rzeszowskiej, który również wygłosił słowo Boże. Zwrócił w nim m.in. uwagę na duchowy cel naukowego spotkania w Sokołowie: „Nic dziwnego, że motywem dzisiejszego spotkania jest myśl o tym, by odwdzięczyć się Matce Najświętszej za to, że stała się Matką Jezusa Chrystusa, a w Nim, że stała się Matką naszą. Wiele razy na tym miejscu i w kościele parafialnym wobec wizerunku Maryi, Królowej Świata - Patronki Ludzkich Dróg doświadczali ludzie na przestrzeni stuleci matczynej bliskości. Nie można wobec tej bliskości przejść obojętnie. I za tę bliskość nie tylko trzeba się wtapiać w maryjne Magnificat «Wielbi dusza moja Pana, raduje się duch mój w Panu, Zbawicielu moim». To Magnificat śpiewają wieki, śpiewają pokolenia, ale do tego Magnificat chcemy dołączyć także i my, jakby sumując głos pokoleń, wyraz wdzięczności w postaci koronacji łaskami słynącego wizerunku".

Do koncelebry włączyło się także kilkunastu kapłanów przybyłych na konferencję. Oprawę muzyczną zapewnił chór młodzieżowy z Sokołowa pod batutą Sebastiana Lesiczki, prezesa sokołowskiego oddziału Katolickiego Stowarzyszenia Młodzieży. Zaznaczyć też trzeba obecność barwnej Straży Grobowej z Dzikowca oraz pocztów sztandarowych Nadleśnictwa Kolbuszowa i miejscowego Zespołu Szkół im. Jana Pawła II.

Obrady konferencyjne toczyły się w sali widowiskowej Miejsko-Gminnego Ośrodka Kultury, Sportu i Rekreacji w Sokołowie Małopolskim. Zgromadziły one ponad sto osób - mieszkańców dekanatów sokołowskiego oraz kolbuszowskiego, w tym m.in.: Dzikowca, Górna, Kątów Trzebuskich, Kolbuszowej, Medyni Głogowskiej, Nienadówki, Sokołowa Małopolskiego, Trzebosi, Trzebuski, Turzy, Wólki Niedźwiedzkiej. Wśród licznych gości nie brakło duchownych. Przybyli proboszczowie $\mathrm{z}$ dekanatu sokołowskiego: kustosz sanktuarium sokołowskiego i proboszcz miejscowej parafii ks. Jan Prucnal, ks. Jan Lib (Górno), ks. Józef Fila

${ }^{1}$ S. Barącz, Cudowne Obrazy Matki Najświętszej w Polsce, Lwów 1891, s. 252. 
(Trzeboś), ks. Józef Galant (Nienadówka), ks. Stanisław Szwanenfeld (Wólka Niedźwiedzka) i dziekan dekanatu sokołowskiego ks. Jan Krzywiński (Medynia Głogowska). Obecni byli również wikariusz sokołowski ks. Paweł Ciba i ks. Marek Wygonik z Górna. Przybyła przełożona placówki Sióstr Służebniczek Najświętszej Maryi Panny Niepokalanie Poczętej w Sokołowie, a także katechetki z Górna i Sokołowa.

Przedstawicieli świata kultury i oświaty reprezentowali: dyrektor Muzeum Diecezjalnego w Rzeszowie ks. mgr Franciszek Dziedzic, Marta Nikiel pracownik Służby Ochrony Zabytków w Rzeszowie, dyrektor Miejskiej i Powiatowej Biblioteki Publicznej w Kolbuszowej Andrzej Jagodziński, dyrektor MiejskoGminnego Ośrodka Kultury, Sportu i Rekreacji w Sokołowie Małopolskim Jacek Piekiełek wraz z pracownicami Elżbietą Słomiany i Henryką Boho, dyrektor Zespołu Oświatowego w Sokołowie Stanisław Jarosz, nauczyciele i dyrektorzy szkół (Lucyna Perlak - ZS Górno, Grażyna Majka - ZS Sokołów, Helena Piróg - ZS Trzeboś, Ireneusz Koziarz - SP Turza, Elżbieta Walicka - SP Wólka Sokołowska), pracownicy instytutów KUL: Instytutu ABMK, Instytutu Leksykografii i Instytutu Badań nad Polonią i Duszpasterstwem Polonijnym. Licznie reprezentowani byli społecznicy i działacze kulturalni: członkowie Towarzystwa Miłośników Ziemi Sokołowskiej z wiceprezesem TMZS Łukaszem Ożogiem, prezes Towarzystwa Przyjaciół Dzikowca Tadeusz Korzeniowski, członkowie Regionalnego Towarzystwa Kultury im. Juliana Macieja Goslara w Kolbuszowej.

Na zaproszenie odpowiedzieli także samorządowcy z terenu gminy: burmistrz sokołowski Andrzej Ożóg z zastępcą Bogusławem Kidą, radni Rady Miejskiej w Sokołowie Małopolskim: Wiesław Nykiel (Sokołów), Franciszek Łuszczki (Sokołów), Karol Chorzępa (Sokołów), Anna Kraska (Trzebuska-Kąty), Bronisława Szot (Turza), Grażyna Pacyna-Tasior (Trzebuska), przewodniczący Zarządu Rady Samorządowej Mieszkańców Sokołowa Małopolskiego Stanisław Kula. Obecna była też: kierownik Zakładu Gospodarki Komunalnej i Mieszkaniowej Zofia Krauz oraz pracownicy Urzędu Gminy i Miasta Jerzy Chorzępa i Genowefa Jabłońska. Właścicieli i prezesów firm reprezentowali: Kazimierz Smolak z Zakładu Mięsnego „Smak” w Górnie i Stanisław Kania z firmy „Kan-Pol” w Sokołowie Małopolskim.

Przedstawicielami młodzieży byli uczniowie: ponagimnazjalnego Zespołu Szkół w Sokołowie Małopolskim, Zespołu Szkół im. Ks. Mieczysława Lachora w Górnie, Zespołu Szkół im. Jana Pawła II w Sokołowie Małopolskim i Zespołu Szkół im. Św. Jadwigi Królowej w Trzebusce. Uroczyste otwarcie konferencji uświetniła również obecność: Straży Grobowej z Dzikowca z komendantem Antonim Twardowskim oraz pocztów sztandarowych Nadleśnictwa Kolbuszowa iZespołu Szkół im. Jana Pawła II w Sokołowie.

Zebranych powitał ks. dr Sławomir Zych z Instytutu Badań nad Polonią i Duszpasterstwem Polonijnym KUL. Odczytał on także nadesłane na ręce organizatorów pismo od ks. infułata Stanisława Jeża, Rektora Misji Katolickiej we Francji, który wyjaśniał swoją nieobecność i życzył owocnych obrad. Swe słowo do zebranych skierował również kustosz sokołowskiego sanktuarium ks. Jan Prucnal: „Opiekunka Ludzkich Dróg - w tym tytule Matka Boża jest nam szcze- 
gólnie bliska. Przyzywamy Jej opieki na wszystkich drogach, którymi chodzimy w ciągu naszego życia, zarówno odmierzających odległość od jednej do drugiej miejscowości, jak i na drogach duchowych. Szczególnie te drugie, drogi duchowe są ważne dla człowieka. Te pierwsze, choć też nie są bez znaczenia, jednakże nie decydują, jakimi jesteśmy ludźmi. Chodzić Bożymi drogami, to najważniejsze dla człowieka. Chodzić Bożymi drogami, to sprawa naszego «kim jesteśmy». Niech ta konferencja naukowa umocni naszą miłość do Matki Najświętszej. Niech też przyczyni się w sposób znaczący do wydarzenia, jakim będzie koronacja Matki Bożej w ikonie Królowej Świata - Matki Bożej Sokołowskiej. Życzę wszystkim głębokich przeżyć podczas tej konferencji”.

Przedstawiciel władz samorządowych, burmistrz Andrzej Ożóg, powiedział: „Wyrażam głęboką wdzięczność wszystkim przybyłym na dzisiejszą konferencję. Jest ona kamieniem milowym na drodze do koronacji łaskami słynącego obrazu Matki Bożej Sokołowskiej - Opiekunki Ludzkich Dróg. Jest to wydarzenie niezwykle ważne i doniosłe dla naszej społeczności. Umacnia nas w wymiarze duchowym, kulturalnym i emocjonalnym. Dla nas, mieszkańców Sokołowa i ziemi sokołowskiej, kult maryjny jest czymś naturalnym, czymś oczywistym, bez czego nie można normalnie żyć. Jest drogowskazem, jest pomocą w życiu codziennym, jest pomocą $w$ trudach i smutkach dnia codziennego. Dzisiejsza konferencja jest wypełnieniem woli, testamentem śp. ks. prał. Mieczysława Wajdy, aby kult maryjny, kult Matki Bożej Sokołowskiej znalazł właściwe miejsce w duszach i sercach mieszkańców Podkarpacia i naszego kraju, bo niewątpliwie jest on wszechobecny w duszach i sercach mieszkańców ziemi sokołowskiej. Te chwile spędzone tu, w Sokołowie Małopolskim, bez wątpienia będą pięknym krokiem do ubogacenia siebie, do poznania dobra absolutnego, jakim jest dla każdego Polaka kult Matki Bożej”.

Pierwszą część konferencji, zatytułowaną „Ku koronacji Opiekunki Ludzkich Dróg”, prowadził ks. dr Stanisław Koza z Instytutu Leksykografii KUL. Stanowiła ją refleksja nad kultem Matki Najświętszej zarówno w wymiarze narodowym, jak i lokalnym. Tematyka wygłoszonych w części pierwszej referatów i komunikatów była dość szeroka - od kwestii biblijnych, historycznych i liturgicznych aż po badania językoznawcze i zagadnienia z literatury i wiedzy o kulturze. Obrady rozpoczął ks. dr Stanisław Ilnicki TChr z Poznania z referatem „Maryja towarzyszką i wypełnieniem drogi Chrystusa". Następnie prof. dr hab. Kazimierz Ożóg, dziekan Wydziału Filologicznego Uniwersytetu Rzeszowskiego, wygłosił wykład „Tytuły Matki Bożej w historii języka polskiego”. Prelegent zwrócił uwagę na stałą obecność Maryi w dziejach kultury i religijności polskiej, wskazał też na bogactwo tytułów, jakimi w języku polskim obdarzona została Maryja. Analizę oparto na ludowych nazwach świąt maryjnych, tekstach pieśni kościelnych, określeniach używanych w stosunku do sanktuariów maryjnych na terenie całego kraju i na Podkarpaciu.

Zarys dziejów kultu Pani Sokołowskiej przedstawił dr Bartosz Walicki, kierownik sokołowskiej książnicy i prezes Towarzystwa Miłośników Ziemi Sokołowskiej. W swoim wystąpieniu wskazał na sięgające XVIII wieku początki kultu maryjnego i jego rozwój odnotowywany w sprawozdaniach z wizytacji biskupich: 
Krzysztofa Jana Szembeka, Walentego Aleksandra Czapskiego oraz Wacława Hieronima Sierakowskiego. Poruszył również kwestie związane z kryzysem kultu w okresie rozbiorów spowodowanym sytuacją polityczną i zaginięciem cudownego obrazu. Omówione zostały zagadnienia ożywienia pobożności maryjnej i ponowny rozkwit kultu cudownego obrazu Matki Bożej Sokołowskiej. Na koniec referent wspomniał także o współczesnym nabożeństwie do Matki Bożej Królowej Świata - Opiekunki Ludzkich Dróg. Wykład zilustrowany został prezentacją multimedialną. Mgr Ewa Kłeczek-Walicka, nauczyciel języka polskiego w Zespole Szkół im. Armii Krajowej w Zaczerniu, omówiła obecność obrazu Matki Bożej Sokołowskiej w podaniach i legendach. Przedmiotem analizy stały się teksty zapisane przez Sadoka Barącza ${ }^{2}$, Krzysztofa Osiniaka ${ }^{3}$, Zbigniewa Trześniowskiego $^{4}$ i Leszka Walickiego ${ }^{5}$. Także i temu wystąpieniu towarzyszyła prezentacja multimedialna.

Pierwszą część konferencji zamknął referat przygotowany przez ks. dr. Waldemara Pałęckiego MSF, asystenta w Instytucie Liturgiki KUL, na temat liturgicznego zwyczaju koronacji wizerunków Maryi w tradycji Kościoła łacińskiego. W zastępstwie nieobecnego referenta wystąpienie odczytał doktorant KUL ks. mgr Grzegorz Wójcik. Zebrani zapoznani zostali z informacjami na temat zwyczaju koronowania obrazów Maryi i celebracji koronacji wizerunków Bogarodzicy na ziemiach polskich. Omówiono również obrzędy koronacji odnotowane w księgach liturgicznych. Z przyczyn technicznych niezależnych od organizatorów nie doszła do skutku multimedialna prezentacja referatu nieobecnego dr. hab. prof. KUL Tomasza Panfila, dyrektora Instytutu Badań nad Polonią i Duszpasterstwem Polonijnym KUL. Po pierwszym bloku tematycznym proboszcz parafii sokołowskiej zaprosił zebranych na obiad przygotowany na stołówce Zespołu Szkół im. Jana Pawła II w Sokołowie.

Poobiednią cześć konferencji otworzył koncert dwudziestokilkuosobowego zespołu wokalno-instrumentalnego „Młody Duch” z Górna. Wystąpił on pod batutą Dariusza Kosaka, nauczyciela Zespołu Szkół im. Ks. Mieczysława Lachora w Górnie. Udział w nim wziął też skrzypek Kamil Niemiec, instruktor Wojewódzkiego Domu Kultury w Rzeszowie. Zaprezentowane utwory religijne zachwyciły obecnych i stanowiły szczególny hołd oddany Matce Bożej i Jezusowi Chrystusowi.

Drugiemu blokowi tematycznemu, zatytułowanemu ,Z Maryją na wychodźczych szlakach", przewodniczył ks. dr Jan Cebulak z Wyższej Szkoły Informatyki i Zarządzania w Rzeszowie. Przedstawiane w tej części treści dotyczyły głównie problematyki emigracyjnej i duszpasterstwa emigracyjnego. Jako pierwszy wystąpiłks. drSławomirZych, pracowniknaukowy Instytutu BadańnadPoloniąi Dusz-

${ }^{2}$ Tamże.

${ }^{3}$ K. Osiniak, Cudowne źródełko, w: Sokołowskie opowieści, red. L. Walicki, K. Osiniak, Sokołów Małopolski 1997, s. 41-42.

${ }^{4}$ Z. Trześniowski, Ozaginionym obrazie w Sokołowie, w: OdRzeszowa ... Legendyiopowieści regionu rzeszowskiego, red. Z. Trześniowski, Rzeszów 2008, s. 90-92.

${ }^{5}$ L. Walicki, Sokołowska Pani, w: Opowieści z Ziemi Sokołowskiej, red. L. Walicki, B. Walicki, Sokołów Małopolski 2003, s. 26-29. 
pasterstwem Polonijnym KULi opiekun naukowy sanktuarium sokołowskiego z ramieniaBiskupa Rzeszowskiego.Podjęty przezniego tematdotyczyłemigracjii opieki duszpasterskiej nad emigrantami w łacińskiej diecezji przemyskiej w świetle synodów z lat 1902, 1908 i 1914. Referent nakreślił przede wszystkim zjawisko emigracji zaistniałe w końcu XIX wieku na terenie zaboru austriackiego ze szczególnym uwzględnieniem diecezji przemyskiej. Przedstawił liczne działania duszpasterskie duchowieństwa, a zwłaszcza ordynariusza bpa Józefa Sebastiana Pelczara, ukierunkowane na opiekę nad wychodźcami. Na tym tle ukazał konkretne rozporządzenia synodalne o charakterze prawnym, liturgicznym oraz ascetycznym.

Z kolei miejscowi regionaliści próbowali rozważyć kwestię emigracji z punktu widzenia społeczności lokalnej, wskazując przyczyny, przebieg i skutki wychodźstwa. Mgr Wojciech Mroczka, członek Zarządu Regionalnego Towarzystwa Kultury im. Juliana Macieja Goslara w Kolbuszowej, omówił wychodźstwo Lasowiaków na przykładzie mieszkańców wsi Lipnica. Prelegent zwrócił uwagę na trzy przyczyny tego zjawiska. Jako pierwszą wymienił galicyjską biedę i chęć polepszenia warunków życia. Drugiej przyczyny upatrywał w obowiązującym w przeszłości prawie (wypełnianie powinności pańszczyźnianej, spełnianie obowiązku obrony ojczyzny, służba wojskowa, zsyłki za działalność patriotyczną). Omówienia doczekały się również kwestie wychodźstwa spowodowanego względami ambicjonalnymi. Następnie mgr Marian Piórek na przykładzie rodziny Straubów z Wildenthalu i Johna Paluszka z Lipnicy zarysował losy emigrantów $z$ terenu dawnej parafii Dzikowiec wyjeżdżających do Brazylii i Stanów Zjednoczonych. Swe rozważania referent bogato zilustrował cytatami pochodzącymi ze wspomnieniowej książki Johna Paluszka Amerykańska podróż $z^{6}$. Dole i niedole emigrantów pochodzących z Nowego Kamienia (dawna kolonia niemiecka) zaprezentowane zostały przez pryzmat wspomnień ks. Tadeusza Waldemara Krausa. W wystąpieniu wykorzystano obszerne passusy z jego książki zatytułowanej $\mathrm{Na}$ drodze życia. W poszukiwaniu zaginionej przeszłości i genealogii w tańcuchu pokolen' .

Kolejny referat, wygłoszony przez ks. dr. Marka Grygiela TChr z Instytutu Historii Kościoła KUL, dotyczył reprezentatywnych sanktuariów maryjnych, odgrywających szczególną rolę na szlakach pielgrzymich Polonii. Scharakteryzowane zostały kolejno: Sanktuarium Matki Bożej Szkaplerznej w Aylesford na Wyspach Brytyjskich, trzy sanktuaria australijskie - Sanktuarium Matki Bożej Pomocy Chrześcijan w Marian Valley koło Brisbane, Sanktuarium Jasnogórskiej Matki Miłosierdzia w Berima i kościół w Marayong pod wezwaniem Matki Bożej Częstochowskiej Królowej Polski. Zaprezentowano również Sanktuarium Matki Bożej Panny Ubogich w belgijskiej miejscowości Banneux, holenderskie Sanktuarium Matki Bożej w Potrzebie w Heiloo, „Westfalską Częstochowę” - Sanktuarium Matki Bożej Wędrowców w Neviges-Velbert koło Wupertalu w Niemczech i szwajcarskie Sanktuarium Czarnej Madonny w Einsiedeln. Obszerne fragmenty

${ }^{6}$ J. Paluszek, An American Jurney, New York 1981.

${ }^{7}$ T. W. Kraus, Na drodze życia. W poszukiwaniu zaginionej przeszłości i genealogii w tańcuchu pokoleń, Krosno 1993. 
wystąpienia poświęcono „Amerykańskiej Częstochowie”.

Ks. dr Józef Szymański z Instytutu Badań nad Polonią i Duszpasterstwem Polonijnym KUL skupił się natomiast na pielgrzymowaniu Polonii norweskiej. W wystąpieniu scharakteryzował krótko emigracyjne środowisko Polaków w Norwegii i trudności, na jakie napotykali przybywający tam duszpasterze. Sporo miejsca poświęcił organizowanej od roku 1985 pieszej pielgrzymce z Oslo do sanktuarium w Mariaholm. Zaprezentowana została też działalność Polskiej Rady Katolickiej funkcjonującej w środowisku polskim przy kościele św. Olava w Os10 .

Konferencję zakończyło wystąpienie ks. dr. Wiesława Wójcika TChr z Instytutu Duszpasterstwa Emigracyjnego w Poznaniu. W pierwszej części swego referatu przedstawił on działania kardynała Augusta Hlonda na rzecz emigrantów, przede wszystkim założenie Towarzystwa Chrystusowego dla Polonii Zagranicznej i Stowarzyszenia „Opieka Polska nad Rodakami na Obczyźnie”, a także Związku Misjonarzy „Dobrego Pasterza”. Ponadto prelegent zwrócił uwagę na aktualność hlondowskiej wizji krajowego duszpasterza emigracyjnego i przypomniał o ćwierćwieczu istnienia i działalności Ruchu Apostolatu Emigracyjnego, którego celem jest spełnianie wszelkiego rodzaju apostolstwa wśród i na rzecz emigrantów.

Po dyskusji uczestnicy konferencji otrzymali pamiątkowe albumy Kościót neogotycki w Sokołowie Małopolskim. Przekazał je kustosz sokołowskiego sanktuarium, ks. kan. Jan Prucnal. Ponadto zebrani obejrzeć mogli towarzyszącą konferencji wystawę „Pod płaszczem Maryi” przygotowaną przez pracowników Miejskiej i Gminnej Biblioteki Publicznej w Sokołowie Małopolskim. Składały się na nią tablice ze zdjęciami dokumentującymi współczesny kult Sokołowskiej Madonny (jedna ukazująca różne grupy pielgrzymkowe zdążające do sanktuarium sokołowskiego, druga - przedstawiająca celebry związane z dorocznym odpustem maryjnym w pierwszą niedzielę października). Zaprezentowano ponadto kopie wydawnictw mówiących o sokołowskim sanktuarium z przełomu stuleci XIX i XX, teksty pięciu lokalnych pieśni maryjnych i współczesne publikacje prasowe poświęcone obrazowi Pani Sokołowskiej.

Zorganizowana w Sokołowie konferencja zapowiadana była w mediach regionalnych m.in. na falach Katolickiego Radia „Via”, na łamach dwumiesięcznika „Podkarpacki Informator Kulturalny” i ,Tygodnika Rodzin Katolickich Niedziela” - dodatek rzeszowski. Sygnalizował ją także rocznik regionalny „Kalendarz Imprez Kulturalnych". Ponadto informacje o tym wydarzeniu znalazły się na stronach internetowych diecezji rzeszowskiej, Instytutu Duszpasterstwa Emigracyjnego i stronie internetowej gminy Sokołów Małopolski. Relacje i sprawozdania medialne poświęcone konferencji zaprezentowane zostały w TVP Rzeszów, Katolickim Radio „Via” i Polskim Radio Rzeszów. Odnotowano je również w rzeszowskim dodatku do „Tygodnika Rodzin Katolickich Niedziela” i na stronach internetowych diecezji rzeszowskiej, Instytutu Duszpasterstwa Emigracyjnego i gminy Sokołów Małopolski. 